\title{
TECHNICAL EFFICIENCY AND ITS DETERMINANTS IN THE SPANISH CONSTRUCTION SECTOR PRE- AND POST-FINANCIAL CRISIS
}

\author{
Magdalena KAPELKO $^{a, *}$, Alfons OUDE LANSINK ${ }^{b}$ \\ a Department of Logistics, Institute of Applied Mathematics, Wroclaw University of Economics, \\ ul. Komandorska 118/120, 53-345 Wroclaw, Poland \\ ${ }^{b}$ Business Economics Group, Wageningen University, Hollandseweg 1, 6706 KN Wageningen, \\ Netherlands
}

Received 6 March 2013; accepted 22 November 2013

\begin{abstract}
This paper estimates technical efficiency in the Spanish construction sector before and after the start of the current financial crisis, and examines the impact of socio-economic factors on technical efficiency. Bias-corrected efficiency measures are obtained using Data Envelopment Analysis with bootstrap for a sample of medium-sized and large construction firms over the period 2000-2010. Next, bias-corrected efficiency scores are regressed on the variables explaining efficiency using bootstrap truncated regression. The results show that technical efficiency is very low and is significantly lower after the beginning of the financial crisis than before. Firms with the highest technical efficiency scores have the lowest input-ratio for material and employee costs to output and the highest for fixed assets. The examination of the determinants of technical efficiency indicates that efficiency is higher for firms that export, are highly leveraged, are integrated in the form of joint stock company, and are located in Spanish regions with higher GDP per capita, while firms with high stock relatively to turnover have lower technical efficiency. Technical efficiency increases with size for relatively small sized construction firms, but decreases beyond a critical firm size, while technical efficiency decreases with age for young firms, but eventually increases for older firms.
\end{abstract}

KEYWORDS: Technical efficiency; Data Envelopment Analysis; Bootstrap truncated regression; Construction sector; Financial crisis

\section{INTRODUCTION}

The Spanish construction sector is the largest among EU countries (Eurostat 2012) and until recently, it enjoyed a period of constant growth, reaching a $10 \%$ share of national GDP in 2006, and employing 2.9 million persons (13\% of the labor force). During the last decade, the expansion of this industry was a driving force behind the Spanish economic growth. In 2006, Spain was recording higher annual new home construction completions than France, Germany and Italy combined. The housing boom was supported by economic expansion, strong employment growth, an immigration boom and low interest rates (International Monetary Fund 2009). In 2006, Spain was among the countries with highest home ownership rate and relatively undeveloped rental market (Interna-

\footnotetext{
* Corresponding author. E-mail: magdalena.kapelko@ue.wroc.pl
}

tional Monetary Fund 2009), while houses were estimated to be overvalued by between $13 \%$ and $30 \%$ (Spanish Ministry of Public Works and Transport 2012). The 2007 financial crisis led to a sudden collapse of Spain's construction industry with many firms exiting the sector (Spanish Ministry of Public Works and Transport 2012; Bielsa, Duarte 2010). The downturn of the construction sector negatively affected both output and employment; both contracted by about one third in the period from 2007 till the end of 2009 (Eurostat 2012). By 2010 , house prices had fallen by over $17 \%$ compared to their peak in 2007 (Spanish Ministry of Public Works and Transport 2012).

The impact of the financial crisis on the Spanish construction sector is demonstrated in Figure 1 presenting the indices of production and employment between 2000 and $2010(2000=100)$. The emerging crisis is clearly foretold during 2006 by 
the beginning of decreasing trend of production volume as indicated by production index. The employment index is showing a similar decrease approximately one year thereafter, in 2007.

Figure 1 shows that the financial crisis clearly had a negative impact on the economic environment in which Spanish construction firms operate and on their output. In the worsening environment in which construction firms operate, their performance is likely to be deteriorating. At the same time, a sound performance is of key importance for firm survival and indicator of firm success. The measurement of firms' performance opens the scope for exploring the sources of performance. Hence, it is interesting to question to what extent the performance of the construction sector was affected by the financial crisis and which specific factors are associated with performance.

The literature on the performance of the construction sector often integrates different methods of performance measurement. The combinations of methods include canonical correlation analysis, Strengths-Weaknesses-Opportunities-Threats (SWOT analysis) and Data Envelopment Analysis (Chiu, Wang 2011), Key Performance Indicators (KPIs) and Data Envelopment Analysis (Horta et al. 2010) or composite performance score of several metrics including schedule performance, cost performance, customer satisfaction, safety performance and profit (El-Mashaleh et al. 2006). This study will use Data Envelopment Analysis as a tool to estimate the performance, i.e. technical efficiency of the construction sector.

Previous literature provides a wide range of technical efficiency levels for the construction sector, ranging from a low of around 50\% for Canadian firms (Pilateris, McCabe 2003), approximately $60 \%$ for Portuguese firms (Horta et al. 2012), to higher estimates of 93\% for Greek firms (Tsolas

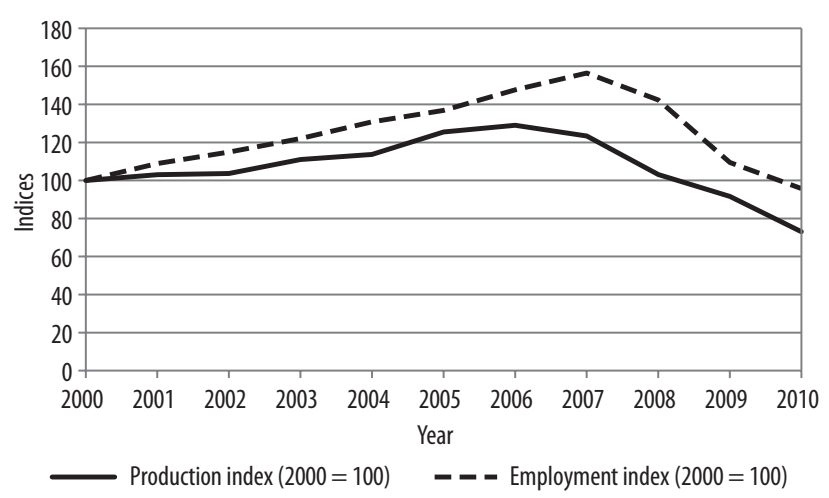

Fig. 1. Production and employment index in Spanish construction

Source: based on the information from Eurostat 2012.
2011) and $84 \%$ and $98 \%$ for Chinese firms (Xue et al. 2008; Zheng et al. 2011). Wong et al. (2012) conducted a study for Iranian real estate and construction companies and concluded that most of firms are technically efficient. Literature provides only one study that analyzed the impact of an economic crisis on the construction sector. The Korean construction sector was impacted by an economic crisis in November 1997 and the impact of this crisis was investigated by You and Zi (2007) using Data Envelopment Analysis. These authors find that efficiency decreased after the economic crisis and that efficiency is affected by leverage ratio, export weight, institutional ownership, asset size and the ratio of annual sales to receivables overdue. Previous studies also analyze the evolution of efficiency and productivity over time of construction sector using a growth accounting approach or a Malmquist index. Li and Liu (2010) show that the productivity growth of the Australian construction sector over 1990-2007 was low, with wide fluctuations over time and across different Australians states. Abdel-Wahab and Vogl (2011) compare productivity growth of construction sectors in Germany, France, UK, USA and Japan over the period 1990-2005. Their analyses show that Germany and Japan present a negative productivity growth rates in construction. In addition, their results also suggest that across all countries this industry has become less efficient in combining the factors of production. Ruddock, L. and Ruddock, S. (2011) provide evidence of a relatively high rate of total factor productivity for the UK construction industry. Xue et al. (2008) for 1997-2003 show that productivity growth in the Chinese construction sector presents wide differences across regions with an industry average of $4.25 \%$ annually, except for the 2001-2002 period which presents an unexplained anomaly. The productivity growth is found to be positive due to technical change, while efficiency change contributes negatively in some periods of time.

Technical efficiency of the construction sector in the context of current financial crisis has not yet been investigated. In particular, the evolution of technical efficiency of the Spanish construction sector before and during the current crisis has neither been measured, nor the factors influencing the efficiency have been investigated. Also, the extensive literature on the technical efficiency of the construction sector does not explicitly consider how input mixes may influence the efficiency scores.

To fill in the gap in the literature outlined above, the objective of this paper is to analyze 
technical efficiency in the Spanish construction sector before and after the start of the financial crisis. Furthermore, this study identifies and evaluates important determinants of technical efficiency and analyses differences in input mixes between quartile groups of firms based on their technical efficiency. These analyses provide insights to managers and policy makers about possible successful strategies towards improving the performance of construction firms and surviving the economic crisis. The contributions of this paper to the literature lie in two main areas. Firstly, this is the first study that analyses the impact of financial crisis on technical efficiency of construction firms for Spanish construction industry. Secondly, this study presents a more innovative analysis of results by analyzing the input mixes for quartile groups based on firms' technical efficiency.

The paper proceeds with the next section presenting the methodological approach used in the paper, followed by the description of the database of financial accounts of Spanish construction firms and the definition of variables. The section to follow presents the results and the final section offers concluding comments and some potential policy implications.

\section{METHODS}

\subsection{Estimation of technical efficiency - Data Envelopment Analysis}

Technical efficiency of the construction firms was identified using Data Envelopment Analysis (DEA), which is a nonparametric method for calculating the efficiency of a sample of $\mathrm{N}$ individual decision-making units (DMU) (Charnes et al. 1978; Banker et al. 1984). DEA compares the levels of inputs and outputs for a given DMU against all other DMUs in the dataset to determine which DMUs are producing at efficient levels relative to the entire group. The concepts of DEA and technical efficiency are illustrated with a simple example in Figure 2. Suppose we have 4 firms: A, B, C and $\mathrm{D}$, each of which uses single input $(x)$ to produce single output $(y)$. Firms A, B, and C are efficient because they use the minimum quantity of $x$ to produce their own quantity of $y$ (so called inputoriented technical efficiency ${ }^{1}$ ). The line connecting $\mathrm{A}, \mathrm{B}$ and $\mathrm{C}$ is called the "efficient frontier". Firm D can decrease its input and still produce the same quantity of output, therefore it is producing at

\footnotetext{
${ }^{1}$ Efficient firms can also be defined as those firms that produce the maximum quantity of output from a given quantity of input (output-oriented technical efficiency).
}

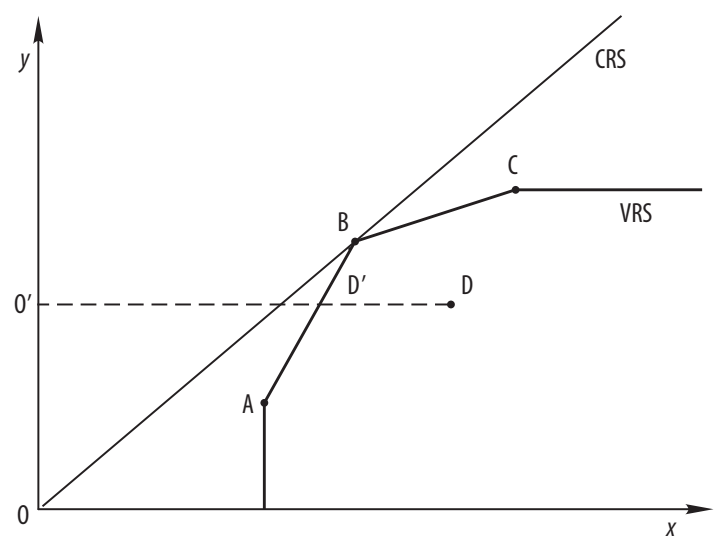

Fig. 2. Input-oriented technical efficiency

an inefficient level. An estimate of input-oriented technical efficiency of firm $\mathrm{D}$ can be obtained by projecting $\mathrm{D}$ on the frontier such that inputs are contracted and output is held constant. For firm $\mathrm{D}$, technical efficiency is calculated as the ratio of O'D'/O'D. Technical efficiency is 1 for efficient firms and between 0 and 1 for inefficient firms. The input-oriented technical efficiency indicates for a given quantity of outputs, the percentage by which input of an inefficient DMU could be decreased if it was producing at the efficient frontier (Cooper et al. 2000). For example, an efficiency of 0.80 implies that input of an inefficient firm can be decreased by $20 \%$ relative to the efficient frontier. Although the example in Figure 2 uses only one input and one output, the DEA method can be applied to production involving multiple inputs and outputs.

DEA models are based on different assumptions about returns to scale, which measure the change in output levels due to a one percent increase of all inputs. The original DEA model proposed by Charnes et al. (1978) assumes constant returns to scale (CRS), while the variable returns to scale model (VRS) is developed by Banker et al. (1984). Constant returns to scale implies that an increase in all inputs results in a corresponding proportional increase in outputs. The CRS line in Figure 2 shows this linear relationship between input and output. Variable returns to scale indicate that an increase in the input levels does not necessarily result in a proportional increase in output levels, that is the output levels can increase more than proportionally (increasing returns to scale) or less then proportionally (decreasing returns to scale) than the increase in all inputs. Geometrically, this means that the linear relationship between input and output in the case of CRS is replaced by a curve with a changing slope as indicated by the 
VRS line in Figure 2, i.e. fixed ratios of input and output in the case of CRS are replaced by changing ratios. In general, the VRS assumption allows that a firm is compared with other firms of a similar size (Coelli et al. 2005).

One of the main drawbacks of the DEA is that its results may be affected by the sampling variation, suggesting that the distances of inefficient firms to the frontier are likely to be underestimated. In order to introduce an error term in efficiency scores a bootstrap algorithm specified in Simar and Wilson (1998) was employed. It allows correcting efficiency scores for the bias and constructing 95-percent confidence intervals for efficiency scores. The basic idea of the bootstrap algorithm is that if the data are viewed as a set of random draws from an underlying population, random draws from the sample are also random draws from the underlying population. Therefore, the known bootstrap distribution will mimic the unknown distribution of the underlying population if the known data generating process is a consistent estimator of the unknown data generating process. After a predetermined number of iterations, a distribution of efficiency scores is obtained that represents an estimate of the true distribution.

All calculations on technical efficiency were performed using the statistical computing software $R$ which was supplemented by the library FEAR 1.13 (Wilson 2008). For calculating the efficiency estimates, an input-oriented efficiency model with a single output and three inputs was applied using a variable returns to scale assumption. The reasons for choosing input orientation are associated with characteristics and current situation of industry under study. Spanish construction firms in times of crisis decrease the employment and reduce the size of factories (Eurostat 2012), which is a clear orientation towards inputs reduction. Therefore, input orientation is consistent with the aim of construction firms to minimize costs.

The FEAR software allows bootstrapping results and adjusting for bias in technical efficiency (because of the upper bound of 1.00 on technical efficiency) as shown by Simar and Wilson (1998). For this study 2000 bootstrap iterations were run. The model determined the technical efficiency of each firm $\mathrm{j}$ with the following linear programming problem:

$$
\begin{array}{ll}
\min \theta_{j} & \\
\text { s.t. } & Y \lambda_{j} \geq y_{j} \\
& \theta_{j} x_{j} \geq X \lambda_{j} \\
& N 1 \lambda_{j}=1 \\
& \lambda_{j} \geq 0,
\end{array}
$$

where: $\theta_{j}$ is the measure of input-oriented technical efficiency of the $\mathrm{j}$-th firm and $\lambda_{j}$ is a $\mathrm{Nx} 1$ vector of constants. In equation (1), $x_{j}$ and $y_{j}$ represent a vector of $k$ inputs used by $\mathrm{DMU} j$ and a scalar of output produced by DMUj, respectively. $Y$ is a $1 \mathrm{xN}$ matrix of outputs produced by the $N$ firms in the sample and $X$ is a $\mathrm{kxN}$ matrix of inputs of the $N$ sample firms. The linear program above is solved once for each DMU, so that efficiency is gauged for each $\mathrm{DMU} j$ relative to each of the other $N$ DMUs in the sample.

\subsection{Analysis of determinants of technical efficiency - bootstrap truncated regression}

The estimates of bias-corrected technical efficiency obtained from Data Envelopment Analysis are regressed on a number of socio-economic factors. Until recently, a common practice was to employ the Tobit regression. However, Simar and Wilson (2007) have noted that DEA efficiency scores are serially correlated in a complicated and unknown manner, and have shown that Tobit estimators fail to account appropriately for the underlying data-generating process. Hence, they are invalid methods for inference. Instead, Simar and Wilson (2007) propose different bootstrap truncated regression approaches and demonstrate their good performance in Monte Carlo experiments. Truncated regression is applied when the values of dependent and independent variables are observed in only some of the ranges and outside these ranges are totally lost (Greene 2003). In our case, only firms with technical efficiency scores lower or equal to 1 are observed, i.e. our dependent variable is right truncated at 1 . In this paper, we follow the approach of Simar and Wilson (2007) outlined in algorithm 2, as this algorithm was found to outperform other approaches. This algorithm uses 1000 bootstrap iterations in which a truncated regression is performed of socio-economic factors on bias-corrected technical efficiency estimates (so called double bootstrap). The algorithm was applied in STATA 10.0. The model we estimate is the following:

$$
\hat{\theta}_{j}=a+F_{j} \beta+\varepsilon_{j}, \quad j=1, \ldots, N,
$$

where: $j$ stands for individual firm; $\hat{\theta}_{j}$ is the inputoriented bias-corrected technical efficiency; $a$ is a constant term; $F_{j}$ is a vector of variables that are expected to affect technical efficiency for firm $j ; \beta$ is a vector of coefficients to be estimated associated with these variables, and $\varepsilon_{j}$ is an error term. 


\section{DATA}

The firm-level data on variables used in the DEA and in the bootstrap truncated regression (except for the regional GDP per capita) are obtained from the SABI database, managed by Bureau van Dijk. The sample includes firms representing the category of firms in construction of residential and non-residential buildings (NACE Rev. 2 code 4120), which is the largest sector within Spanish construction industry. This study focuses on medium-sized and large firms which are among the most adversely impacted by the crisis as reflected by the significant reduction in the number of firms (Laborda 2012). Also, focusing on medium and large-sized firms results in a data set with firms that are more comparable in size. Despite this delimitation, there is still wide variation in the sample of firms studied as, according to the definition of European Union, medium firms employ between 50 and 250 employees and have an annual turnover of between 10 and 50 million euros, while large firms employ more than 250 employees and have an annual turnover larger than 50 million euros (European Commission 2003).

The final data set, i.e. after filtering out companies with missing information and after removing the outliers ${ }^{2}$, consists of 4928 firms that operated in Spain in at least one year during the period from 2000 to 2010. Choosing this time span we are able to analyze the years before and after the start of the financial crisis in Spain. The panel is unbalanced and it sums up to 32273 observations.

Following You and Zi's (2007) study of the construction sector and other efficiency studies of different industries (Kapelko, Oude Lansink 2013; Soboh et al. 2012), one output and three inputs (material costs, employee costs and fixed assets) are used. Output was defined as operating revenues (turnover) and was deflated using the price index of residential buildings $(2000=100)$. Turnover is an accounting item from firms' profit and loss account directly taken from the SABI database and it includes total sales and other operating revenues. Material costs and employee costs

\footnotetext{
$\overline{2}$ Following Geylani and Stefanou (2013), outliers were determined using ratios of output to input. An observation was defined as an outlier if the ratio of output over any of the three inputs was outside the interval of the median plus and minus two standard deviations. After cleaning procedures there were 33317 observations left, out of which 1044 (3.1\% of the sample) were identified as outliers. There are also alternative methods for outliers' detection; these include, for example, the proposals of Wilson (1993) or Simar (2003).
}

were also directly taken from the SABI database and were deflated using the price indexes of materials of residential buildings and labor costs in construction, respectively. Material costs refer to expenses on raw materials, parts, subassemblies, components as well as expenses associated with getting materials into the company (such as inbound transportation and in-transit insurance). Employee costs are the sum of all wages paid to employees, as well as the cost of employee benefits and payroll taxes paid by an employee. Fixed assets are a proxy measure for firms' capital. The measurement of capital is a very complex issue and there is no universally accepted method for its measurement. Several approaches to capital assessment can be distinguished in the efficiency and productivity literature. Many studies employ the perpetual inventory method or a variant of it (Christensen, Jorgenson 1969) and this is a preferable measure of capital stock. However, this method is very data- and time-intensive as it requires a long time series of data on past investment and depreciation of the existing capital stock. This method has been applied in some construction studies (for example, Abdel-Wahab, Vogl 2011 and Ruddock, L., Ruddock, S. 2011). Yet another approach derives from the fact that the flow of output is linked to the flow of inputs' services. As no data on the flow of capital services is available, the method assumes that capital flows are proportional to net capital stock after depreciation (Mahadevan 2003). Hence, capital is approximated by the book value of fixed assets and this method is extensively applied in many studies (for construction sector see for example, Xue et al. 2008; You, Zi 2007). Finally, capital is also approximated by the user costs of capital which are the sum of depreciation expenditures, interests costs on capital stock, maintenance costs and costs of hiring machines (for example Odeck 2009). The data available in this study only allow us to use the second method of approximating the capital by the book value of fixed assets. Fixed assets were directly taken from the firms' balance sheet data in SABI and were deflated using the industrial price index for capital goods. They comprise of tangible and intangible assets and financial investments, net of depreciation. All prices used to deflate output and inputs were obtained from the Spanish Statistical Office $(2012)^{3}$. Table 1 provides the descriptive statistics

\footnotetext{
${ }^{3}$ In addition to the deflation of variables, no other transformation of variables was undertaken before running the DEA model.
} 
of the data used in this study, for the whole period 2000-2010 and for the periods before the start of the financial crisis (i.e. from 2000 to 2006) and after the start of the financial crisis (i.e. from 2007 to 2010).

Table 1. Descriptive statistics of input-output data, preand post-financial crisis, constant 2000 prices, mln euro

\begin{tabular}{llll}
\hline Variable & Mean & Std. dev. & $\begin{array}{l}\text { Coefficient } \\
\text { of variation }\end{array}$ \\
\hline 2000-2006 $(\mathrm{N}=21108)$ & & & \\
Fixed assets & 3.114 & 101.418 & 32.568 \\
Employee cost & 1.853 & 19.956 & 10.770 \\
Material cost & 6.698 & 59.021 & 8.812 \\
Operating revenues & 10.520 & 96.568 & 9.179 \\
2007-2010 $(\mathrm{N}=11165)$ & & & \\
Fixed assets & 9.902 & 408.056 & 41.209 \\
Employee cost & 2.305 & 38.469 & 16.689 \\
Material cost & 8.157 & 54.790 & 6.717 \\
Operating revenues & 13.590 & 159.091 & 11.706 \\
2000-2010 $(\mathrm{N}=32273)$ & & & \\
Fixed assets & 5.462 & 253.656 & 46.440 \\
Employee cost & 2.010 & 27.793 & 13.827 \\
Material cost & 7.203 & 57.596 & 7.996 \\
Operating revenues & 11.582 & 121.890 & 10.524 \\
\hline
\end{tabular}

The data in Table 1 show that the sizes of all variables are larger in the period after the start of the financial crisis than before. This shows that, on average, the construction firms have grown in the period under consideration. This finding may be because smaller firms in terms of their inputs and output have more often gone bankrupt or disappeared from the sample in the period 2007-2010. On the other hand, the relative differences between firms, as measured by the coefficient of variation, are much larger after the crisis than before the crisis for all variables except material costs. This finding reflects that firms reacted very differently to the crisis. Therefore, although on average firms in the sample have grown with regard to their inputs and output, there are large differences between firms and many of them scaled down after the start of the financial crisis ${ }^{4}$. The data in Table 1 reflects the wide variation in the sample of firms as shown by the large values of variables' standard deviations with regard to their respective means.

The data used in the second stage bootstrap truncated regression are described in Table 2.

\footnotetext{
${ }^{4}$ More reliable conclusions about the effect of crisis on firms' inputs and outputs could be obtained by looking at the same set of firms before and after the start of financial crisis, hence in the balanced panel setting.
}

Table 2. Descriptive statistics of the variables used in the bootstrap truncated regression (monetary values are expressed in constant 2000 prices)

\begin{tabular}{llll}
\hline Variable & Description & Mean & Std. dev. \\
\hline Joint Stock & $\begin{array}{l}\text { Dummy = 1 if the firm } \\
\text { is a joint stock company }\end{array}$ & 0.319 & 0.466 \\
Cooperative & $\begin{array}{l}\text { Dummy = 1 if the firm } \\
\text { is a cooperative }\end{array}$ & 0.002 & 0.049 \\
Age & $\begin{array}{l}\text { Age of the company } \\
\text { in years }\end{array}$ & 13.338 & 10.037 \\
Status & $\begin{array}{l}\text { Dummy = 1 for firms } \\
\text { that remained active }\end{array}$ & 0.770 & 0.421 \\
Export & $\begin{array}{l}\text { Dummy = 1 if the firm } \\
\text { exports }\end{array}$ & 0.023 & 0.149 \\
Size & $\begin{array}{l}\text { Value of total assets } \\
\text { (billion euro) }\end{array}$ & 0.018 & 0.354 \\
Stock to & $\begin{array}{l}\text { Ratio of value of stock } \\
\text { to turnover }\end{array}$ & 2.919 & 200.212 \\
Lurnover & $\begin{array}{l}\text { Ratio of debt to total } \\
\text { assets }\end{array}$ & 0.811 & 1.696 \\
GDerage & $\begin{array}{l}\text { Ln of regional GDP } \\
\text { per capita }\end{array}$ & 9.694 & 0.211 \\
\hline
\end{tabular}

Joint stock and Cooperative are dummy variables that indicate the ownership structure of construction firms. Limited liability firms form the reference situation for both variables. Joint stock companies, cooperatives and limited liability may provide different incentives to firm managers to produce efficiently. Joint stock companies are publicly traded and are owned by shareholders (private persons, institutions) who usually do not work in the company themselves. Shareholders often put pressure on joint stock companies to generate high returns to equity. Cooperatives and limited liability companies are usually owned by private persons that work in the company themselves. Moreover, cooperatives may pursue other objectives than maximizing profit which could negatively affect their technical efficiency (Soboh et al. 2012).

Age is measured as the number of years since the firm was established. Age may have different effects on technical efficiency. One stream of research suggests that young firms suffer from liability of newness (Stinchcombe 1965). As firms become older, their actions result to be more reliable and exhibit less variance. Another stream of literature suggests that young firms tend to start with more up-to-date technologies than firms already in place currently employ, resulting in relatively higher technical efficiency ${ }^{5}$. As technologies

\footnotetext{
$\overline{5}$ Although the construction industry is known for its low-tech nature and relatively slow technological progress, one may still expect that newly established firms will begin their operations with newer technologies than those that were available for firms that are already in place.
} 
decay with time, technical efficiency may decrease. Also, technical efficiency may decrease over time as older firms are locked in fixed procedures and are less sensitive to market signals (Ahuja, Majumdar 1998; Marshall 1920). On the other hand, young firms may gradually improve their technical efficiency as they benefit from increased experience in the business. Therefore, the theory suggests a non-linear relation between age and technical efficiency, i.e. technical efficiency might either decrease or increase with age and this relation may reverse over time. The most common method used in regression models to account for such a non-linearity is a power transformation of an explanatory variable, specifically squaring the explanatory variable (Greene 2003). Therefore, we add the quadratic term of firm age in our regression model ${ }^{6}$.

Size is measured as the value of total assets and indicates the presence of economies or diseconomies of scale in technical efficiency improvements. Larger firms may more quickly take up new technologies, which translates into higher technical efficiency. Also, large firms may benefit from better opportunities for specialization within the firm and can sustain competitive advantage due to economies of scale, economies of scope and market power which are expected to improve technical efficiency (Penrose 1959). In addition, large firms may benefit from pecuniary economies of scale that is from cost savings resulting, for example, from buying raw material in large quantities at lower prices than smaller firms (Scitovsky 1954). On the other hand, managers of larger firms face more problems of internal coordination, leading to a lower technical efficiency (Ahuja, Majumdar 1998). Also efficiency can decline with an increase in firm size because workers in large firms more often work routinely which causes boredom and diminishes creativity, and because flexibility of decision making is reduced (Färe et al. 1985). Because the link between size and efficiency may follow a non-linear relationship, we also enter in the model the squared term of size, for reasons already outlined while describing the effect of age.

As firm age and firm size may interact in shaping firm efficiency we include the interaction term between the two variables.

\footnotetext{
${ }^{6}$ If the expected relationship between explanatory and dependent variable is even more complex, one could consider adding a cubic term into the regression. However, the theoretical literature does not provide the argument for such a relation between age and efficiency.
}

Status is a dummy variable that indicates whether the firm remained active (value equal to one) or went bankrupt during the time period under investigation. A priori, it is expected that firms that went bankrupt operate at a lower technical efficiency. Firm's technical inefficiency was proved as a good predictor of enterprise's failure (Xu, Wang 2009), while some studies conducted in banking show that technically inefficient banks were more likely to fail than technically efficient banks (Wheelock, Wilson 1995). This variable is relevant in our analysis, because the economic crisis in Spain has forced many construction firms to quit business.

Export is a dummy variable which takes the value one for firms that are active in international markets. Firms that export may operate more efficiently as they have to comply with stricter requirements of international markets and are exposed to more intensive competition (Aw, Hwang 1995; Delgado et al. 2002). Also, firms that export may generate more cash to finance investments in new technologies. Another hypothesis for the explanation of superior efficiency of exporting firms refers to self-selection of more efficient firms into exports markets based on incurrence of sunk entry cost to this markets (Delgado et al. 2002). Therefore, only firms that are efficient enough to comply with entry costs will start exporting. Many empirical studies conducted in different sectors show a positive association between exporting and efficiency (Aw, Hwang 1995; Kapelko, Oude Lansink 2013). In the face of decreased demand during crisis, many Spanish construction firms tend to undertake construction projects in foreign countries in order to survive (Spanish Ministry of Public Works and Transport 2012).

Stock to turnover is the ratio of stock (value of inventories) and turnover. Firms that maintain higher stocks relative to their turnover are expected to operate less efficiently. In the case of construction firms, stocks indicate the value of residential and nonresidential buildings that have not yet been sold (both finished and not finished). Spanish construction firms suffer from excessive stocks of buildings, and especially houses, not sold (Vergés 2011).

Leverage is the ratio of accounting value of debt to accounting value of total assets and represents the impact of increasing debt relative to total assets on technical efficiency. On the one hand, debts are expected to increase technical efficiency as they are expected to reduce agency costs such as luxury cars and offices. Agency costs may also be reduced 
because banks that supply credits to firms may impose restrictions on companies so as to improve the debt repayment potential of firms. Therefore, debt issuing can put pressure on managers to perform better (Jensen 1986; Margaritis, Psillaki 2007). Whereas debts may reduce agency costs, increasing debt may eventually reduce the scope for firms to invest in new up-to-date technologies. Therefore, the existence of debt can weaken the firm's incentives to undertake good future investments because they will benefit only debtholders, not shareholders (Myers 1977). Also with debt issuing, the manager might have a strong incentive to engage in riskier activities (Jensen, Meckling 1976). If investment goes well, the manager receives all gains, but if it goes badly, the debtholder will pay the consequences. Hence, a larger debt may decrease technical efficiency too. Spanish construction firms used debt excessively during the period under investigation. The external debt was designated to unproductive sector (Vergés 2011).

$G D P$ is the natural logarithm of GDP per capita in the region in which the main office of the construction firm is located and it is obtained from the Spanish Statistical Office. Higher GDP per capita triggers a higher demand for construction services and may induce firms to charge higher prices that increase profitability, but reduce incentives of firms to operate efficiently. However, growth of GDP may also attract new construction firms to the market, which eventually increases competition. The increased competition may force firms to operate efficiently in order to survive. Also, economic development is positively correlated with the level of infrastructure and human capital, which in turn positively affects the efficient use of resources in firms (Stavárek 2006). This variable is relevant in case of Spain, which is a country in which disparities in regional income per capita are considerable and have increased over the last decades.

\section{RESULTS}

This section presents the analysis of technical efficiency in the Spanish construction sector for the period pre- and post-financial crisis. The frontier was computed separately for every year in the data set, since we are interested in the extent to which producers use their current production potential. Furthermore, efficiency indicators are regressed on factors that explain efficiency.

Table 3 presents the bias-corrected technical efficiencies in the period 2000-2010 and the upper and lower bounds of the $95 \%$ confidence interval.
Table 3. Evolution of bias-corrected technical efficiency

\begin{tabular}{lllll}
\hline Year & N & $\begin{array}{l}\text { Bias-corrected } \\
\text { technical efficiency }\end{array}$ & $\begin{array}{c}\text { Lower } \\
\text { bound }\end{array}$ & $\begin{array}{l}\text { Upper } \\
\text { bound }\end{array}$ \\
\hline 2000 & 2175 & 0.336 & 0.311 & 0.368 \\
2001 & 2529 & 0.443 & 0.415 & 0.479 \\
2002 & 2920 & 0.426 & 0.399 & 0.461 \\
2003 & 3132 & 0.316 & 0.292 & 0.349 \\
2004 & 3318 & 0.423 & 0.398 & 0.454 \\
2005 & 3472 & 0.399 & 0.372 & 0.433 \\
2006 & 3562 & 0.309 & 0.285 & 0.341 \\
2007 & 3325 & 0.151 & 0.137 & 0.193 \\
2008 & 2898 & 0.233 & 0.213 & 0.260 \\
2009 & 2710 & 0.143 & 0.128 & 0.166 \\
2010 & 2231 & 0.218 & 0.197 & 0.249 \\
$-\overline{2000-2006}$ & 21108 & 0.378 & ---- & - \\
$2007-2010$ & 11165 & 0.184 & 0.352 & 0.411 \\
$2000-2010$ & 32273 & 0.311 & 0.288 & 0.215 \\
\hline
\end{tabular}

Technical efficiency is on average 0.311 in the period 2000-2010, indicating that Spanish construction firms could have reduced their use of inputs by, on average, $68.9 \%$ in order to be fully efficient. Therefore, there is a substantial scope for improvements in technical efficiency of construction firms in the sample. The difference between the lower and upper bound of the $95 \%$ confidence interval of technical efficiency is less than 0.06 indicating the average technical efficiency is estimated accurately. The technical efficiency of construction firms is low when compared with most previous studies on the construction sector, but is in the range found by Pilateris and McCabe (2003) for Canada. Results in the period before and after the beginning of the crisis show that technical efficiency is substantially lower after the beginning of the crisis by 0.194 . This finding goes in line with You and Zi (2007) who, in the context of Korean crisis of 1997, show that efficiency of construction firms decreased after the economic crisis. The $95 \%$ confidence intervals of technical efficiency in the periods before and after the beginning of the crisis do not overlap, so the difference in technical efficiency is significant at the $5 \%$ critical level.

The evolution of technical efficiency in the period 2000-2010 in Table 3 shows that the beginning of the current crisis, the year 2007, marks a clear drop in technical efficiency compared to all years in the period 2000-2006. Moreover, technical efficiency remains low in the entire period after the beginning of the current crisis.

It is worth noticing that the low values of efficiency found in this study might be caused by possible misspecification of DEA model related to, 
for example, the omission of significant input or output variables, the inclusion of irrelevant variables or inappropriate assumption about returns to scale. The dangers of misspecification are less serious when sample sizes are large (Smith 1997), as in our case. Another possible factor impacting the values of efficiency scores is the unbalanced nature of the panel data in this study. This impact on technical efficiency can be both positive and negative. The impact is positive when it is the case that firms that leave the sample have a lower performance than those that stay in business. It will be negative if it is the case that firms that enter the market initially have lower efficiency scores due to lack of experience. The literature is not clear on the impact of unbalanced versus balanced panel data on DEA efficiency scores. However, it is emphasized that using a balanced panel (and deleting all observations of firms entering and leaving the sector from the sample) results in a substantial loss of information (Kerstens, Van de Woestyne 2013). Hence, the preference would be to apply unbalanced panel data ${ }^{7}$.

Next, we analyze differences in input mixes between quartile groups that were constructed based on the firms' bias-corrected technical efficiencies ${ }^{8}$. Through the analysis of input mixes by quartile groups of firms based on their efficiency scores insights can be obtained in the relation between input mixes and technical efficiency scores. Also, the analysis by quartile groups allows for a more detailed analysis of this relation for the entire distribution of technical efficiency scores. This would not be possible when analyzing technical efficiency scores for groups based on a firm characteristic. After calculating the bias-corrected efficiency scores, we applied the following ranking procedure. First, firms were ranked according to their magnitudes of bias-corrected efficiency scores and then the firms were grouped by quartiles of biascorrected efficiency. The first quartile reflects the

\footnotetext{
$\overline{7}$ Note that in the second stage analysis we control for some part of the impact of unbalanced panel, because we introduce the variable of status which differentiates between firms that remain active for the whole period and firms that go bankrupt at some point in time.

${ }^{8}$ We separate this analysis from the truncated regression due to the following reason. Input-output ratios similarly to efficiency scores represent the characterization of firms' technology. So efficiency scores and input-output ratios present "two sides of the same coin". Therefore, including these ratios in the truncated regression would not be appropriate as we would have the same items at both sides of the regression's equation.
}

$25 \%$ observations with the lowest (I) bias-corrected technical efficiency scores and the last quartile reflects the $25 \%$ of the observations with the highest (IV) technical efficiency scores. In the next step, for each quartile group, the mean ratios of input to output were calculated and the differences in ratios between quartiles were tested using a nonparametric Wilcoxon test ${ }^{9}$. Table 4 presents the analysis of differences in input mixes, as reflected by input-output ratios, between quartile groups of firms' bias-corrected technical efficiency scores.

The overall average ratios (last row) in Table 4 indicate that material cost to operating revenues accounts for the largest ratio and employee cost to operating revenues accounts for the lowest ratio. A closer look at the values of the four quartiles tells a more subtle story. The ratios of employee costs and material costs to operating revenues are lower for quartile groups with higher technical efficiency. Also, the ratio of fixed assets to operating revenues decreases when moving from the first to the third quartile group. However, the quartile group with the highest technical efficiency scores has a significantly higher ratio of fixed assets to operating revenues than the three quartile groups with lower technical efficiency. Hence, the quartile group with the highest technical efficiency uses the lowest ratios of material and employee costs to operating revenues and the highest ratio of fixed assets to operating revenues. This suggests that construction firms in the sample achieve a better performance by using relatively more fixed assets such as machinery and equipment. Results in Table 4 also show that the differences between the lowest and highest quartile groups in the ratios of material costs and employee costs are relatively small (approximately 0.04 in both cases), whereas the variation among quartile groups is much larger for the ratio of fixed assets to operating revenues. This suggests that fixed assets are an important determinant of technical efficiency. The results of the Wilxocon test show that almost all differences between quartile groups in input-output ratios are significant at the $5 \%$ critical level, except for the difference between the lowest and lower middle quartile groups for the ratio of material costs to operating revenues.

The results before and after the beginning of the crisis suggest that the crisis had a negative

\footnotetext{
9 The Wilcoxon test is appropriate for this analysis as we test for the differences between input-output ratios, and not between bias-corrected efficiency scores.
} 
Table 4. Input-Output ratios by quartile groups of bias-corrected technical efficiency scores

\begin{tabular}{llll}
\hline $\begin{array}{l}\text { Quartile group of bias-corrected } \\
\text { technical efficiency }\end{array}$ & $\begin{array}{l}\text { Fixed assets/operating } \\
\text { revenues }\end{array}$ & $\begin{array}{l}\text { Employee } \\
\text { cost/operating revenues }\end{array}$ & $\begin{array}{l}\text { Material cost/operating } \\
\text { revenues }\end{array}$ \\
\hline Lowest (I) & $0.405^{\mathrm{a}}$ & $0.209^{\mathrm{a}}$ & $0.661^{\mathrm{a}}$ \\
Lower middle (II) & $0.306^{\mathrm{b}}$ & $0.207^{\mathrm{b}}$ & $0.655^{\mathrm{a}}$ \\
Upper middle (III) & $0.251^{\mathrm{c}}$ & $0.177^{\mathrm{c}}$ & $0.631^{\mathrm{b}}$ \\
Highest (IV) & $0.570^{\mathrm{d}}$ & $0.160^{\mathrm{d}}$ & $0.605^{\mathrm{c}}$ \\
All & 0.472 & 0.174 & 0.622 \\
\hline
\end{tabular}

Notes: a,b,c,d significant differences between quartile groups at the critical $5 \%$ level.

impact on technical efficiency. However, in order to more precisely identify the effect of the crisis on technical efficiency, it is necessary to control for the potential role of other factors. This is what is achieved in the bootstrap truncated regression. The results of this regression i.e. coefficients and the upper and lower bounds of the $95 \%$ confidence interval are presented in Table 5.

Table 5. Results of bootstrap truncated regression

\begin{tabular}{llll}
\hline & Coefficient & $\begin{array}{l}\text { Lower } \\
\text { bound }\end{array}$ & $\begin{array}{l}\text { Upper } \\
\text { bound }\end{array}$ \\
\hline Constant & 0.235 & 0.225 & 0.244 \\
Size & 0.353 & 0.311 & 0.393 \\
Size $^{2}$ & -0.007 & -0.007 & -0.006 \\
Age & -0.002 & -0.003 & -0.002 \\
Age $^{2}$ & $5.3 \mathrm{E}-05$ & $4.4 \mathrm{E}-05$ & $6.2 \mathrm{E}-05$ \\
Size $\times$ Age & -0.003 & -0.004 & -0.003 \\
Cooperative & 0.005 & -0.025 & 0.036 \\
Joint stock & 0.027 & 0.023 & 0.031 \\
Status & -0.001 & -0.004 & 0.003 \\
Export & 0.039 & 0.029 & 0.048 \\
Stock to turnover & $-5.5 \mathrm{E}-06$ & $9.0 \mathrm{E}-06$ & 0 \\
Leverage & $8.5 \mathrm{E}-04$ & $4.0 \mathrm{E}-06$ & $1.8 \mathrm{E}-03$ \\
Ln regional & $3.6 \mathrm{E}-06$ & $3.0 \mathrm{E}-06$ & $4.0 \mathrm{E}-06$ \\
GDP per capita & & & \\
\hline
\end{tabular}

The results of the bootstrap truncated regression in Table 5 show that 11 of the 13 parameters are significant at the $5 \%$ critical level. Size has a positive impact on technical efficiency, although the positive effect is leveling off as suggested by the negative coefficient of Size $^{2}$ and the overall effect may become negative for very large firms. This suggests that larger firms are, ceteris paribus, operating at more efficient levels than smaller firms within the sample of analyzed medium-sized and large firms, although the size advantage gradually disappears. The interaction effect of size and age is negative, implying that the positive (negative in case of large firms) effect of size is, ceteris paribus, smaller for older firms. The interaction term also implies that older firms have a lower optimal size than younger firms.
The impact of Age on technical efficiency takes a U-shape. This result suggests that technical efficiency is higher for recently established firms which might be explained by the fact that the firm uses a more up-to-date technology. In the initial years, after establishing the company the technical efficiency is gradually decreasing, suggesting that technologies are gradually degrading relative to the state of the art. However, after a number of years, the technical efficiency is improving, possibly as a result of increased experience in the business or by replacement investments that improve the technology employed. The combined effect of size and age shows that bigger firms experience a larger drop in technical efficiency in the initial years and benefit less from increased experience.

Technical efficiency of cooperatives does not differ significantly from technical efficiency of limited liability companies. Joint stock companies, on the other hand, have a significantly higher technical efficiency than limited liability companies, suggesting that the incentive structure within joint stock companies induces the firms to produce technically more efficiently than limited liability companies. Joint stock companies are publicly traded and their performance is much more transparent than the performance of limited liability companies. Joint stock companies also face a constant pressure from shareholders who require improvements in the return on equity.

The parameter of Status is not significantly different from zero at the critical 5\% level, implying that the technical efficiency of firms that went bankrupt during the period under investigation does not differ from firms that remained active. Hence, it seems that the status of firms is not important in explaining the technical efficiency of construction firms. It suggests that for construction firms in the sample, there are other factors than efficiency of firms that are related to bankruptcy.

The parameter of Export shows that firms that undertake export activities have significantly higher (0.039) technical efficiency than firms that do 
not export. This result suggests that firms that export and are faced with the requirements of international markets and increased competition have stronger internal incentives than firms that do not export. Also, technically more efficient firms may be better in finding resources to address the needs of international markets.

The parameter of Stock to turnover, as expected, is negative and significant at $5 \%$, suggesting that firms maintaining a higher stock relative to turnover are operating less efficiently.

Leverage has a significant and positive impact on technical efficiency, implying that firms that have more debt relative to total assets, ceteris paribus, have a higher technical efficiency. This result provides support for the agency theory, which suggests that more indebted firms have lower agency costs, i.e. debt provides a disciplinary role for managers so that they make less unnecessary expenses such as luxury cars, offices and equipment.

The parameter of Ln regional GDP per capita is significant and positive. The value of $3.6 \mathrm{E}-06$ means that a one percent increase in GDP per capita in the region, increases the technical efficiency by $3.6 \mathrm{E}-06$. Higher GDP per capita leads to an increasing demand for construction services, which could attract newcomers to the market. The newcomers could increase competition which forces firms to enhance technical efficiency.

The evolution of the year effects in the period 2000-2010 is displayed in Figure $3^{10}$. Note, that in the regression model we used the year 2006 as the reference year in order to capture the impact of the beginning of financial crisis on the firms' efficiency. This figure shows that the annual dummies are all significant at the $5 \%$ critical level, implying the year effects of 2000-2005 and 2007-2010 are significantly different from the base year 2006. It also shows that the year effects are all negative from 2007 on. Therefore, the results in Figure 3 and Table 5 suggest that the economic crisis had a significant negative effect on technical efficiency of Spanish construction firms. Hence, the economic crisis has worsened the economic environment in which firms operate to such an extent that it worsened their performance. The main explanation for the effect of the economic crisis is the reduction in construction activity which causes underutilization of the available capacity of construction equipment and permanent labor.

\footnotetext{
${ }^{10} \mathrm{We}$ include the year dummies in the regression, because efficiency scores vary between years for reasons that are not adequately captured by the explanatory variables in the model. Therefore, not including the time trend may lead to omitted variable bias.
}

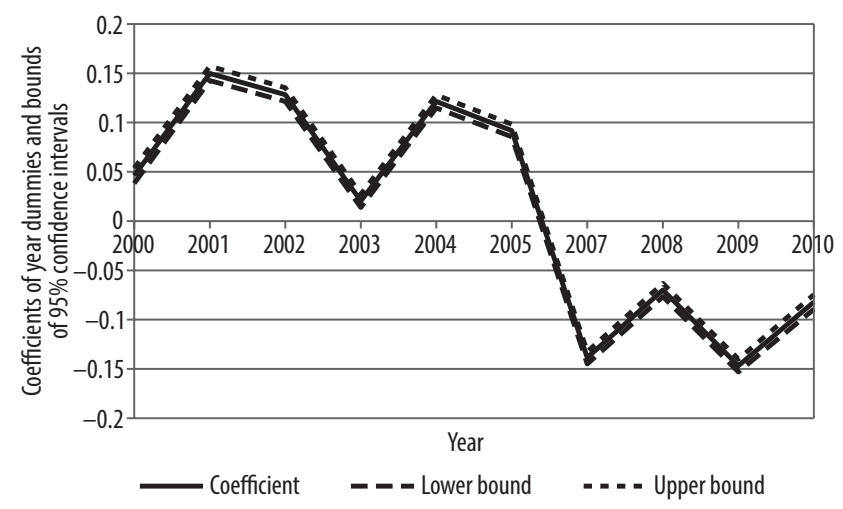

Fig. 3. Evolution of coefficients of the year dummies with 95\% confidence intervals, 2000-2010

(2006 reference year)

\section{CONCLUSIONS}

This paper used Data Envelopment Analysis to estimate technical efficiency of a panel of Spanish firms active in the construction of residential and non-residential buildings over the period 2000-2010. Next, bootstrap truncated regression was used to regress technical efficiency on socioeconomic variables. This study contributes to the literature on construction industry, because no previous study has assessed the impact of the current economic crisis on the performance of Spanish construction firms. Moreover, this study contributes by analyzing differences in input-output ratios between quartile groups based on bias-corrected efficiency scores.

The results show that technical efficiency of the Spanish construction firms is low and is significantly lower after the beginning of the financial crisis than before. This also holds after controlling for the impact of changes in the socio-economic factors on technical efficiency as indicated by the results of the year dummies. Furthermore, the results show that the quartile group with the highest technical efficiency scores has the lowest input-output ratio for employee costs and material costs and the highest input-output ratio for fixed assets. Moreover, variation among quartile groups is much bigger for the input-output ratio of fixed assets than material and employee costs. The results also demonstrated that exporting, leverage, joint stock ownership and regional Gross Domestic Product per capita increase technical efficiency, whereas the ratio of stock relatively to turnover decreases technical efficiency. The results also suggest an inverted U-shaped relation between size and technical efficiency, indicating that size increases technical efficiency for relatively small sized firms, but eventually decreases technical 
efficiency once firms pass a critical size. The relation with age suggests that technical efficiency decreases with age for young firms, but eventually increases for older firms.

The results of this study provide insight into the potential of construction firms to survive the economic crisis, therefore it provides several insights to construction managers on how to improve performance and cope with the current challenges of economic downturn. Previous research suggested that technically efficient firms more likely survive in the long run. Hence, factors affecting technical efficiency positively (exporting, leverage, joint stock ownership and GDP per capita in the region) are also expected to be the factors that will contribute positively to the survival of the firm. Firms with large stocks relative to turnover are expected to have more problems in surviving the crisis. The significant negative impact of the year dummies after the beginning of the economic crisis suggests that the performance of construction firms is much smaller after the beginning of the crisis. Underutilization of the capacity (capital, labor) due to the sharp reduction of construction activity is one explanation for the deterioration of performance. Firms can improve their technical performance by reducing the size of the fixed costs relative to variable costs, enabling for quick cost reductions in periods of economic downturn. Also, more flexibility of the labor market, allowing firms to more easily lay off workers would help firms in keeping up their technical performance in periods of economic downturn. The findings of this paper are also important for policy makers, and industry analysts which are concerned about the competitiveness of construction sector. In the light of findings of this paper, the policy makers should establish incentives to encourage export activities of construction firms as this is associated with higher chances of surviving the economic crisis. Also, the local governments have their role to play, which is indicated by the positive impact of regional GDP per capita on technical efficiency of construction firms. The results of this study show that policies enhancing the size of equity vis-a-vis debt decrease the performance of construction firms. Finally, the findings about the negative impact of excessive stocks of construction firms on their performance suggests that firms would benefit from government policies that decrease the stocks of unsold buildings and constructions. This could be done in the form of preferential credits for possible buyers of new houses. As reducing the stock of unsold buildings and constructions is key to the construction firms' improvement of performance, the authori- ties can also support the construction industry by launching efforts to re-activate the rental market of real estate. The implication for strategic property management is that a more rapid reduction of the stock of unsold buildings and constructions could be achieved by activating foreign demand and/or destine part of the stock for renting.

\section{REFERENCES}

Abdel-Wahab, M.; Vogl, B. 2011. Trends of productivity growth in the construction industry across Europe, US and Japan, Construction Management and Economics 29: 635-644. http://dx.doi.org/10.1080/01446 193.2011.573568

Ahuja, G.; Majumdar, S. K. 1998. An assessment of the performance of Indian state-owned enterprises, Journal of Productivity Analysis 9: 113-132. http://dx.doi. org/10.1023/A:1018352415813

Aw, B. Y.; Hwang, A. 1995. Productivity and the export market: a firm-level analysis, Journal of Development Economics 47: 313-332. http://dx.doi. org/10.1016/0304-3878(94)00062-H

Banker, R. D.; Charnes, A.; Cooper, W. W. 1984. Some models for estimating technical and scale inefficiencies in data envelopment analysis, Management Science 30: 1078-1092. http://dx.doi.org/10.1287/ mnsc.30.9.1078

Bielsa, J.; Duarte, R. 2010. Size and linkages of the Spanish construction industry: key sector or deformation of the economy?, Cambridge Journal of Economics 35: 317-334. http://dx.doi.org/10.1093/cje/ beq016

Charnes, A.; Cooper, W. W.; Rhodes, E. 1978. Measuring the efficiency of the decision making units, European Journal of Operational Research 2: 429-444. http:// dx.doi.org/10.1016/0377-2217(78)90138-8

Chiu, Ch.-Y.; Wang, M.-W. 2011. An integrated DEAbased model to measuring financial performance of construction companies, WSEAS Transactions on Business and Economics 1(8): 1-15.

Christensen, L. R.; Jorgenson, D. W. 1969. The measurement of U.S. real capital input, 1929-1967, Review of Income and Wealth 15: 293-320. http://dx.doi.org/10.1111/j.1475-4991.1969.tb00814.x

Coelli, T.; Rao, D. S. P.; Battese, G. E. 2005. An introduction to efficiency and productivity analysis. Springer.

Cooper, W. W.; Seiford, L. M.; Tone, K. 2000. Data envelopment analysis: a comprehensive text with models, applications, references and DEA-Solver software. Kluwer Academic Publishers.

Delgado, M.; Fariñas, J. C.; Ruano, S. 2002. Firm productivity and export markets: a non-parametric approach, Journal of International Economics 57: 397422. http://dx.doi.org/10.1016/S0022-1996(01)00154-4

El-Mashaleh, M. S.; O’Brien, W. J.; Minchin, R. 2006. Firm performance and information technology utilization in the construction industry, Journal of Construction Engineering and Management 132(5): 499-507. http://dx.doi.org/10.1061/(ASCE)07339364(2006)132:5(499) 
European Commission 2003. Recommendation concerning the definition of micro, small and medium-sized enterprises, Official Journal of the European Union. Available at: http://eur-lex.europa.eu/LexUriServ/LexUriServ.do?uri=OJ:L:2003:124:0036:0041:EN:PDF

Eurostat 2012. Available at: http://epp.eurostat. ec.europa.eu

Färe, R.; Grosskopf, S.; Lovell, C. A. K. 1985. The measurement of efficiency of production. Kluwer Academic Publishers. http://dx.doi.org/10.1007/978-94-0157721-2

Geylani, P.; Stefanou, S. E. 2013. Linking investment spikes and productivity growth, Empirical Econom ics 45(1): 157-178. http://dx.doi.org/10.1007/s00181012-0599-8

Greene, W. 2003. Econometric analysis. Prentice Hall.

Horta, I. M.; Camanho, A. S.; Moreira da Costa, J. 2010. Performance assessment of construction companies: integrating key performance indicators and data envelopment analysis, Journal of Construction Engineering and Management 136(5): 581-594. http:// dx.doi.org/10.1061/(ASCE)CO.1943-7862.0000145

Horta, I. M.; Camanho, A. S.; Moreira da Costa, J. 2012. Performance assessment of construction companies: a study of factors promoting financial soundness and innovation in the industry, International Journal of Production Economics 137: 84-93. http://dx.doi. org/10.1016/j.ijpe.2012.01.015

International Monetary Fund 2009. Spain: Selected issues, Country report No. 09/129. International Monetary Fund, Washington, D.C.

Jensen, M. C. 1986. Agency costs of free cash flow, corporate finance and takeovers, American Economic Review 76: 323-339.

Jensen, M. C.; Meckling, W. H. 1976. Theory of the firm: managerial behavior, agency costs and capital structure, Journal of Financial Economics 76: 323-339.

Kapelko, M.; Oude Lansink, A. 2013. The technical efficiency of the Spanish dairy processing industry. Do size and exporting matter?, in Mendes, A. B. (Ed.). Efficiency measures in the agricultural sector, with applications. Springer, 93-106.

Kerstens, K.; Van de Woestyne, I. 2013. Comparing Malmquist and Hicks-Moorsteen productivity indices: exploring the impact of unbalanced $v s$. balanced panel data, European Journal of Operational Research 233(3): 749-758.

Laborda, A. 2012. How many firms were taken by crisis? [¿Cuantas empresas se ha llevado la crisis?]. Economic report ESADE [Informe económico ESADE].

Li, Y.; Liu, Ch. 2010. Malmquist indices of total factor productivity changes in the Australian construction industry, Construction Management and Economics 28: 933-945. http://dx.doi. org/10.1080/01446191003762231

Mahadevan, R. 2003. To measure or not to measure total factor productivity growth, Oxford Development Studies 31(3): 365-378. http://dx.doi. org/10.1080/1360081032000111742

Margaritis, D.; Psillaki, M. 2007. Capital structure and firm efficiency, Journal of Business Finance and Accounting 34: 1447-1469.
Marshall, A. 1920. Principles of economics. Macmillan.

Myers, S. 1977. Determinants of corporate borrowing, Journal of Financial Economics 5(2): 147-175. http:// dx.doi.org/10.1016/0304-405X(77)90015-0

Odeck, J. 2009. Statistical precision of DEA and Malmquist indices: a bootstrap application to Norwegian grain producers, Omega 37: 1007-1017. http:// dx.doi.org/10.1016/j.omega.2008.11.003

Penrose, E. T. 1959. The theory of the growth of the firm. Basil Blackwell.

Pilateris, P.; McCabe, B. 2003. Contractor financial evaluation model (CFEM), Canadian Journal of Civil Engineering 30(3): 487-499. http://dx.doi. org/10.1139/102-098

Ruddock, L.; Ruddock, S. 2011. Evaluation of trends in the UK construction industry using growth and productivity accounts, Construction Management and Economics 29: 1229-1239. http://dx.doi.org/10.1080/ 01446193.2011 .645494

Scitovsky, T. 1954. Two concepts of external economies, Journal of Political Economy 62(2): 143-151. http:// dx.doi.org/10.1086/257498

Simar, L. 2003. Detecting outliers in frontier models: a simple approach, Journal of Productivity Analysis 20(3): 391-424. http://dx.doi. org/10.1023/A:1027308001925

Simar, L.; Wilson, P. W. 1998. Sensitivity analysis of efficiency scores: how to bootstrap in nonparametric frontier models, Management Science 44: 49-61. http://dx.doi.org/10.1287/mnsc.44.1.49

Simar, L.; Wilson, P. W. 2007. Estimation and inference in two-stage, semi-parametric models of production processes, Journal of Econometrics 136(1): 31-64. http://dx.doi.org/10.1016/j.jeconom.2005.07.009

Smith, P. 1997. Model misspecification in Data Envelopment Analysis, Annals of Operations Research 73: 233-252. http://dx.doi.org/10.1023/A:1018981212364

Soboh, R.; Oude Lansink, A.; Van Dijk, G. 2012. Efficiency of cooperatives and investor owned firms revisited, Journal of Agricultural Economics 63(1): 142-157. http://dx.doi.org/10.1111/j.1477-9552.2011.00324.x

Spanish Ministry of Public Works and Transport (Ministerio de Fomento) 2012. Adjustment of the Spanish real estate sector. Available at: http://www.fomento.gob.es/NR/rdonlyres/D02CD420-9CF2-4E91AB0B-B37F66B94565/109402/adjspa_real_estate_ JAN2012.pdf [accessed 10 November 2012]

Spanish Statistical Office (Instituto Nacional de Estadística) 2012. Monthly statistical bulletin. Available at: http://www.ine.es [accessed 20 September 2012]

Stavárek, D. 2006. Banking efficiency in the context of European integration, Eastern European Economics 44(4): 5-31. http://dx.doi.org/10.2753/EEE00128775440401

Stinchcombe, A. L. 1965. Social structure and organizations, in J. G. March. Handbook of organizations. Rand McNally, 142-193.

Tsolas, I. E. 2011. Modeling profitability and effectiveness of Greek listed construction firms: an integrated DEA and ratio analysis, Construction Management and Economics 29: 795-807. http://dx.doi.org/10.108 0/01446193.2011.610330 
Vergés, R. 2011. The information asymmetry in the Spanish real estate sector. Crisis and stocks [La información asimétrica en el sector inmobiliario español. Crisis y stocks], Observatorio inmobiliario y de la construcción 48: 52-59.

Wheelock, D. C.; Wilson, P. W. 1995. Explaining bank failures: deposit insurance, regulation and efficiency, Review of Economics and Statistics 77(4): 689-700. http://dx.doi.org/10.2307/2109816

Wilson, P. W. 2008. FEAR: a software package for frontier efficiency analysis with R, Socio-Economic Planning Sciences 42(4): 247-254. http://dx.doi. org/10.1016/j.seps.2007.02.001

Wilson, P. W. 1993. Detecting outliers in deterministic nonparametric frontier models with multiple outputs, Journal of Business and Economic Statistics 11(3): 319-323.

Wong, W. P.; Gholipour, H. F.; Bazrafshan, E. 2012. How efficient are real estate and construction companies in Iran's close economy?, International Journal of Strategic Property Management 16(4): 392-413. http://dx.doi.org/10.3846/1648715X.2012.740513

Xu, X.; Wang, Y. 2009. Financial failure prediction using efficiency as a predictor, Expert Systems with Applications 36: 366-373. http://dx.doi.org/10.1016/j. eswa.2007.09.040

Xue, X.; Shen, Q.; Wang, Y.; Lu, J. 2008. Measuring the productivity of the construction industry in China by using DEA-based Malmquist productivity indices, Journal of Construction Engineering and Management 134(1): 64-71. http://dx.doi.org/10.1061/ (ASCE)0733-9364(2008)134:1(64)

You, T.; Zi, H. 2007. The economic crisis and efficiency change: evidence from the Korean construction industry, Applied Economics 39: 1833-1842. http:// dx.doi.org/10.1080/00036840600690199

Zheng, X.; Chau, K.-W.; Hui, E. C. M. 2011. Efficiency assessment of listed real estate companies: an empirical study of China, International Journal of Strategic Property Management 15(2): 91-104. http:// dx.doi.org/10.3846/1648715X.2011.582739 